\title{
Zygosity Misclassification of Twins at Birth in Japan
}

\author{
Syuichi Ooki',Yoshie Yokoyama ${ }^{2}$, and Akio Asaka ${ }^{3}$ \\ ' Department of Health Science, Ishikawa Prefectural Nursing University, Tsu7-I Nakanuma, Takamatsu, Kahoku, Ishikawa, Japan \\ ${ }^{2}$ Department of Health Science, School of Medicine, Kyoto University, 53 Kawahara-cho, Shogoin, Sakyo-ku, Kyoto, Japan \\ ${ }^{3}$ Joto Hospital, Joto Kofu,Yamanashi, Japan
}

\begin{abstract}
$T_{\text {in }}^{\text {ho }}$ hough twinning rates have been rapidly increasing in Japan, the problem of zygosity misclassification at birth has been paid little attention. By analyzing four independent samples, the authors found that at a constant rate about $25-30 \%$ of monozygotic twins were misclassified as dizygotic twins at birth. This percentage is in very good accordance with that of monozygotic twins having dizygous placenta. Generally the obstetricians informed twins' parents about their children's zygosity. The number of placentas, as informed by obstetricians, was very strongly associated with zygosity. Concluding, even now many monozygotic twins in Japan may be misclassified as dizygotic at birth by obstetricians based solely on the number of placenta.
\end{abstract}

There are two types of twins, and they have different origins. Monozygotic (MZ) twins derive from the division of a single zygote, whereas dizygotic (DZ) twins derive from the independent release and subsequent fertilization of two ova. Zygosity determination is the process of determining whether same-sex twin pairs are $M Z$ or DZ, since different-sex pairs are always DZ.

In Japan, multiple birth rates, including rates for twins, have been increasing since 1975 . The higher DZ twinning rate since 1987 has been attributed to the higher proportion of mothers treated with ovulation-inducing hormones and partially attributed to in-vitro fertilization (Imaizumi \& Nonaka, 1997). Multiple birth rates are increasing in developed countries worldwide. The Council of Multiple Birth Organization (COMBO) of the International Society for Twin Studies (ISTS) adopted, in 1996, the Declaration of Rights and Statement of Needs of Twins and Higher Order Multiples. The declaration includes the statement "Parents have a right to expect accurate recording of placentation and diagnosis of zygosity of same-sex multiples at birth". The three important reasons for determining zygosity at birth are (1) medical, (2) scientific and (3) personal (Derom et al., 2001).
It has been recognized that many $\mathrm{MZ}$ twins are misdiagnosed at birth as being DZ because they have dizygotic placentas (Machin, 1994). In Japan, this problem has been acknowledged several times, though it has never been addressed directly because of the difficulty of collecting information on both determined zygosity and zygosity reported at birth, since there is no population-based twin registry. It is especially difficult to obtain data on determined zygosity by blood sample because zygosity testing is seldom routinely performed, including at birth. The focus of the present study is to estimate the circumstance of zygosity misclassification in Japan using reports of twins' mothers.

\section{Participants and Methods Participants}

The sample of the present study consisted of four independent participant groups, which are summarized in Table 1. All participants were mothers of same-sex twin pairs. The first group of participants consisted of 564 mothers, who were all members of The Japanese Association of Twins' Mothers (JATM), the largest association for the mothers of multiples, with about 3000 members all around Japan. The second group of participants consisted of 225 mothers of applicants to the secondary education school attached to the Faculty of Education of the University of Tokyo. This school was established in 1948, and since that time, about 10-20 twin pairs have entered the school every year and participated in the studies of education, psychology, and so on. The third group of participants consisted of 112 mothers of the readers of the quarterly magazine TWINS, which is the only Japanese magazine for the parents of multiples published by Bindeballe Publishing

Received 18 August, 2003; accepted 26 February, 2004.

Address for correspondence: Syuichi Ooki, Department of Health Science, Ishikawa Prefectural Nursing University, Tsu7-1 Nakanuma, Takamatsu, Kahoku, Ishikawa, 929-1212, Japan. Email: sooki@kj8.so-net.ne.jp 
Table 1

Description of the Sample

\begin{tabular}{|c|c|c|c|c|c|c|c|}
\hline & $N$ & Data Source & Residence & $\begin{array}{l}\text { Birth Year } \\
\text { of Twins }\end{array}$ & $\begin{array}{l}\text { Methods of } \\
\text { Data Collection }\end{array}$ & $\begin{array}{l}\text { Zygosity } \\
\text { Determination }\end{array}$ & $\begin{array}{l}\text { Year of Data } \\
\text { Collection }\end{array}$ \\
\hline First group & 564 & $\begin{array}{l}\text { The Japanese } \\
\text { Association of } \\
\text { Twins' Mothers }\end{array}$ & $\begin{array}{l}\text { All around } \\
\text { Japan }\end{array}$ & 1960-1988 & $\begin{array}{l}\text { Mailed } \\
\text { questionnaire }\end{array}$ & Questionnaire & 1989 \\
\hline Second group & 225 & $\begin{array}{l}\text { Applicants to the } \\
\text { secondary school }\end{array}$ & $\begin{array}{l}\text { Tokyo } \\
\text { metropolitan area }\end{array}$ & 1984-1991 & $\begin{array}{l}\text { Handed } \\
\text { questionnaire and } \\
\text { interview }\end{array}$ & $\begin{array}{l}\text { Questionnaire } \\
\text { or DNA/genetic } \\
\text { markers }\end{array}$ & 1997-2003 \\
\hline Third group & 112 & $\begin{array}{l}\text { Readers of } \\
\text { quarterly magazine } \\
\text { TWINS }\end{array}$ & All around Japan & 1987-2001 & $\begin{array}{l}\text { Mailed } \\
\text { questionnaire }\end{array}$ & Questionnaire & 2001 \\
\hline Fourth group & 730 & $\begin{array}{l}\text { The Japanese } \\
\text { Association of } \\
\text { Twins' Mothers }\end{array}$ & All around Japan & 1986-2002 & $\begin{array}{l}\text { Mailed } \\
\text { questionnaire }\end{array}$ & Questionnaire & 2001-2002 \\
\hline
\end{tabular}

Company in Tokyo. The fourth group of participants was a further 730 mothers of JATM. There was no overlap of participants.

\section{Data Collection}

The authors collected information on zygosity by means of a questionnaire, which included questions that assist in zygosity determination, including what the reported zygosity was and when, where, and by whom zygosity was reported. Mothers' knowledge of and interest in their children's zygosity and the reason was also asked. The question items were not always the same for all four groups because these data were not necessarily collected at the same time or for the same purpose. For the second group of participants, the reported number of placenta was also asked. Reported number of placenta was classified as follows: one, two and "never told".

\section{Preliminary Analysis}

Reported zygosity was classified as follows: "told MZ", "told DZ", "told both MZ and DZ" and "never told" (including being told "do not know"). We regarded told $\mathrm{MZ}$ and/or $\mathrm{DZ}$ to be told. The percentage of told any zygosity, namely $\mathrm{MZ}$ and/or DZ, was calculated, as well as by whom it was reported. The result is shown in Table 2. About $80-90 \%$ of mothers were told their children's zygosity by an obstetrician irrespective of participant group. Therefore, the problem of zygosity misclassification appears to occur at birth in maternity hospitals and so on.

\section{$\overline{\text { Method }}$}

The usefulness of zygosity determination by questionnaire was widely accepted (Rietveld et al., 2000), the questionnaire used in this study being one of the commonly used questionnaires in Japan (Ooki et al., 1993, 2004). Zygosity was determined according to the given cut-off point on the single summed raw score for the five question items. The authors adopted strict criteria of zygosity determination in this study, with total accuracy of $98 \%$ leaving about $10 \%$ of participants unclassified. Zygosity was determined using many genetic markers, as well as the zygosity questionnaire, for $26 \%(58 / 225)$ of the second group.

\section{Table 2}

Answer to the Questions as to Reported Zygosity

\begin{tabular}{|c|c|c|c|c|c|c|c|}
\hline & \multirow{3}{*}{$\begin{array}{c}\begin{array}{c}\text { Told MZ } \\
\text { and/or DZ }\end{array} \\
\mathrm{N}(\%)\end{array}$} & \multirow{3}{*}{$\begin{array}{c}\begin{array}{c}\text { Told “Do } \\
\text { not know” }\end{array} \\
\mathrm{N}(\%)\end{array}$} & \multirow{3}{*}{$\begin{array}{c}\text { Never Told } \\
\mathrm{N}(\%)\end{array}$} & \multicolumn{4}{|c|}{ If Told Any Zygosity, Where and/or by Whoma } \\
\hline & & & & \multicolumn{2}{|c|}{ Obstetrics } & \multirow{2}{*}{$\begin{array}{c}\text { Pediatrics } \\
\text { Totalc }^{c} \\
(\%)\end{array}$} & \multirow{2}{*}{$\begin{array}{r}\text { Others } \\
\text { Total } \\
(\%)\end{array}$} \\
\hline & & & & $\begin{array}{c}\text { Obstetrician } \\
(\%)\end{array}$ & $\begin{array}{l}\text { Others } \\
(\%)\end{array}$ & & \\
\hline $\begin{array}{l}\text { First group } \\
(N=564)\end{array}$ & $494(87.6)$ & $70(12.4)^{\mathrm{d}}$ & & $94.2^{\mathrm{e}}$ & & 4.8 & 4.1 \\
\hline $\begin{array}{l}\text { Second group } \\
(N=225)\end{array}$ & $89(79.5)$ & $12(10.7)$ & $11(9.8)$ & 93.3 & 11.2 & 5.6 & 3.4 \\
\hline $\begin{array}{l}\text { Third group } \\
(N=112)\end{array}$ & $166(73.8)$ & $10(4.4)$ & $49(21.8)$ & 86.1 & 15.7 & 8.4 & 3.6 \\
\hline $\begin{array}{l}\text { Fourth group } \\
(N=730)\end{array}$ & $583(79.9)$ & $82(11.2)$ & $65(8.9)$ & 90.2 & 9.6 & 4.6 & 4.5 \\
\hline
\end{tabular}


Zygosity testing included, for example, ABO, CcDEe, MNSs, Haptoglobin, Acid phosphatase, Glutamate pyruvate transaminase, Estrase D, HLA-DR, DNA polymorphisms (e.g., beta-globin gene cluster haplotype, Dopamine receptor gene: DRD4, Serotonine receptor gene: 5-HTT, and mtDNA 9bp deletion), and related tests by blood sample. As a rule twins and their parents were examined. If all markers are concordant for certain twin pairs, the probability of being MZ calculated using Bayes theorem is more than .9999. The second group was divided into two subgroups by the method of zygosity determination. Zygosity diagnosis using many genetic markers was undertaken prior to the zygosity questionnaire. If zygosity determination by DNA/genetic markers was regarded as gold-standard, the accuracy of zygosity questionnaire was $100 \%$ (52/52), though $10 \%(6 / 58)$ of pairs were not classified by questionnaire.

The percentage of zygosity misclassification was estimated by the following method. The zygosity determined by questionnaire or genetic markers and that reported at birth were compared. Reported zygosity at birth was classified as follows: told MZ, told DZ, told both $\mathrm{MZ}$ and $\mathrm{DZ}$, and never told (including being told do not know). If mothers were told their children's zygosity not at birth, but later, for example during their children's infancy, those data was regarded as never told. If mothers were told both MZ and DZ separately at birth, the authors carefully checked the data source, and counted both $M Z$ and DZ according to the number of reported times.

Next, the relationship between told zygosity and the number of placenta, or between determined zygosity and the number of placenta was analyzed using the data of the second participant group by Fisher's exact test. In this analysis the method of zygosity determination was not taken into account because of small sample size.

The authors analyzed data using SAS for Windows version 6.12 (SAS Institute, 1993).

\section{Results}

The frequency of being told any zygosity at birth was calculated according to the birth year of twins, combining all participants. Of the total of 1631 twin pairs, birth year was confirmed for 1496 pairs $(91.7 \%)$. From 1960 to 1979 , the percentage of mothers told any zygosity was 90.4\% (85/94). From 1980 to 1989 , the percentage was $80.4 \%$ (502/624), and from 1990 to 2002 , the percentage was $80.1 \%$ (623/778).

The results of told zygosity according to classified zygosity are summarized in Table 3 . The percentage of $\mathrm{MZ}$ pairs who were reported to be $\mathrm{DZ}$ at birth was about $25-29 \%$ through all samples. There was no significant difference of misclassification ratio concerning MZ misclassified as DZ between all five groups divided by the method of zygosity determination (likelihood ratio Chi-square is $0.274, d f=3, p=.965$ ). On the other hand, the percentage of $\mathrm{DZ}$ pairs reported to be $M Z$ ranged from $7 \%$ to $31 \%$ and was sample dependent. In total, $\mathrm{MZ}$ pairs who were reported to be DZ was estimated to be $26 \%$ and DZ pairs who were reported to be $M Z$ was estimated to be $11 \%$.

The $2 \times 2$ contingency tables between classified or told zygosity and the number of placenta are shown

Table 3

Zygosity Classified by Questionnaire or Genetic Markers and Told Zygosity at Birth

\begin{tabular}{|c|c|c|c|c|c|c|c|c|}
\hline & $\begin{array}{c}\text { Zygosity } \\
\text { Determination }\end{array}$ & & Told MZ & Told DZ & $\begin{array}{l}\text { Told both } \\
\text { MZ and DZ }\end{array}$ & $\begin{array}{l}\text { Percentage of } \\
\text { Misclassification }\end{array}$ & $\begin{array}{l}\text { MZ/DZ } \\
\text { Ratio }\end{array}$ & $\begin{array}{c}\text { Percentage of } \\
\text { Unclassified }\end{array}$ \\
\hline $\begin{array}{l}\text { First group } \\
(n=449)\end{array}$ & Questionnaire & $\begin{array}{l}\mathrm{MZ} \\
\mathrm{DZ} \\
\mathrm{XZ}\end{array}$ & $\begin{array}{r}228 \\
14 \\
11\end{array}$ & $\begin{array}{l}77 \\
96 \\
20\end{array}$ & $\begin{array}{l}0 \\
1 \\
2\end{array}$ & $\begin{array}{c}25.2 \% \\
13.4 \% \\
-\end{array}$ & 2.75 & $7.3 \%$ \\
\hline \multirow[t]{2}{*}{$\begin{array}{l}\text { Second group } \\
(n=159)\end{array}$} & $\begin{array}{l}\text { Genetic } \\
\text { markers }(n=46)\end{array}$ & $\begin{array}{l}\mathrm{MZ} \\
\mathrm{DZ}\end{array}$ & $\begin{array}{r}25 \\
3\end{array}$ & $\begin{array}{l}7 \\
8\end{array}$ & $\begin{array}{l}2 \\
1\end{array}$ & $\begin{array}{l}25.0 \% \\
30.8 \%\end{array}$ & 2.83 & \\
\hline & $\begin{array}{l}\text { Questionnaire } \\
\quad(n=113)\end{array}$ & $\begin{array}{l}\mathrm{MZ} \\
\mathrm{DZ} \\
\mathrm{XZ}\end{array}$ & $\begin{array}{r}68 \\
2 \\
9\end{array}$ & $\begin{array}{r}23 \\
7 \\
2\end{array}$ & $\begin{array}{l}2 \\
0 \\
0\end{array}$ & $\begin{array}{c}26.3 \% \\
22.2 \% \\
-\end{array}$ & 10.33 & $9.7 \%$ \\
\hline $\begin{array}{l}\text { Third group } \\
(n=87)\end{array}$ & Questionnaire & $\begin{array}{l}\mathrm{MZ} \\
\mathrm{DZ} \\
\mathrm{XZ}\end{array}$ & $\begin{array}{r}44 \\
2 \\
4\end{array}$ & $\begin{array}{r}13 \\
10 \\
5\end{array}$ & $\begin{array}{l}8 \\
0 \\
1\end{array}$ & $\begin{array}{c}28.8 \% \\
16.7 \% \\
-\end{array}$ & 5.42 & $11.5 \%$ \\
\hline $\begin{array}{l}\text { Fourth group } \\
(n=549)\end{array}$ & Questionnaire & $\begin{array}{l}\mathrm{MZ} \\
\mathrm{DZ} \\
\mathrm{XZ}\end{array}$ & $\begin{array}{r}222 \\
10 \\
24\end{array}$ & $\begin{array}{r}65 \\
171 \\
38\end{array}$ & $\begin{array}{l}14 \\
3 \\
2\end{array}$ & $\begin{array}{c}25.1 \% \\
7.0 \% \\
-\end{array}$ & 1.64 & $11.7 \%$ \\
\hline $\begin{array}{l}\text { Total } \\
(n=1244)\end{array}$ & & $\begin{array}{l}\mathrm{MZ} \\
\mathrm{DZ} \\
\mathrm{XZ}\end{array}$ & $\begin{array}{r}587 \\
31 \\
48\end{array}$ & $\begin{array}{r}185 \\
292 \\
65\end{array}$ & $\begin{array}{c}26 \\
5 \\
5\end{array}$ & $\begin{array}{c}25.6 \% \\
10.8 \% \\
-\end{array}$ & 2.43 & $9.5 \%$ \\
\hline
\end{tabular}

Note: $\mathrm{MZ}=$ monozygotic, $\mathrm{DZ}$ = dizygotic, $\mathrm{XZ}$ = unknown zygosity

Only those participants who were told their children's zygosity at birth and zygosity determination was completed were analyzed.

For the second group, zygosity determination using genetic markers were adopted prior to zygosity questionnaire. 
Table 4

Relationship Between Told Zygosity at Birth and Determined Zygosity or Number of Placenta

\begin{tabular}{lcccc}
\hline & \multicolumn{2}{c}{ Determined zygosity } & \multicolumn{2}{c}{ Reported number of placenta } \\
& MZ & DZ & one & two \\
\hline Told MZ & 63 & 26 & 66 & 5 \\
Told DZ & 6 & 10 & 3 & 31 \\
\hline
\end{tabular}

Fisher's
exact test $\quad p<.05 \quad p<.0001$

in Table 4. Told zygosity and the number of placenta were very strongly associated, with significance level of $p<.0001$, whereas weak association, with significance level of $p<.05$, was found between determined zygosity and told zygosity by Fisher's exact test.

\section{$\overline{\text { Discussion }}$}

The percentage of $\mathrm{MZ}$ pairs who were reported to be DZ at birth was about $25-30 \%$ through all samples. This percentage was in very good accordance with that of MZ twins having dizygous placenta. According to Machin (1994), the percentage of MZ twins having dizygous placenta is estimated to be between one fourth and one third. Told zygosity was very strongly associated with the number of placenta, whereas determined zygosity was weakly associated with told zygosity, as shown in Table 4 . These results suggest that even now zygosity misclassification of $\mathrm{MZ}$ twins as being DZ at birth may occur based on easy placental findings in Japan. As present data was obtained only from twins' mothers, and not from obstetricians, another possibility is that mothers mistake the told number of placenta for zygosity. This possibility cannot be denied, as we have no information from obstetricians or other medical specialists. In Japan there are no data as to the training, knowledge, and opinion of obstetricians in hospitals or clinics regarding multiple births, containing numbers of placenta and zygosity. It seems rather difficult to obtain unbiased data from medical specialists in Japan.

Though not shown in this article, we have asked mothers about their interest in their children's zygosity and the reasons. About $70 \%$ of mothers showed their interest in their children's zygosity for many reasons. One of the main reasons was their doubt about the zygosity they were told at birth. Although decreasing, about $80 \%$ of mothers are told their children's zygosity at birth. Considering all of these issues, medical specialists, who have much more knowledge than mothers, should be careful what advice they give mothers about zygosity, placenta and related information.

There are several limitations in this study. First, and the largest, was the information bias already mentioned resulting from the collection of the data only from mothers.

Second, the imbalance toward MZ twins and small sample size of $D Z$ pairs concerning second and third sample groups. The $\mathrm{MZ} /$ same-sex $\mathrm{DZ}$ ratio in Japan was about 4:1 in 1975 and 2:1 in 1994 using data of vital statistics (Imaizumi \& Nonaka, 1997). Perhaps the MZ/DZ ratio is now slightly decreasing because of the increase of $\mathrm{DZ}$ twining rate resulting from treatment for infertility. The percentage of DZ pairs who were told they were MZ from the second and third groups may be influenced by sample size itself. For the first and total participant groups, the $\mathrm{MZ} / \mathrm{DZ}$ ratio is appropriate. The authors thought that the total percentage of zygosity misclassification was not so influenced by the imbalance towards $M Z$ twins and small sample size of DZ pairs.

Third, the accuracy of zygosity determination using questionnaires is not $100 \%$; therefore, zygosity misclassification by zygosity questionnaire itself could occur. Total sample size of MZ pairs was relatively large and we adopted strict criteria of zygosity determination. The percentage of MZ pairs misclassified as DZ seemed not so influenced by the accuracy of the zygosity questionnaire.

As the MZ/same-sex DZ ratio in Japan is about 4:1 in 1975 and 2:1 in 1994 as mentioned above, the percentage of $\mathrm{MZ}$ in all the same-sex twin pairs who were told they were $\mathrm{DZ}$ is roughly estimated to be $30 \%$ (MZ/same-sex DZ ratio is 2:1 and one fourth of $\mathrm{MZ}$ have two placenta) to $60 \%$ (MZ/same-sex DZ ratio is $4: 1$ and one third of $M Z$ have two placenta). This percentage cannot be overlooked, and maybe, self-reported zygosity is not always reliable.

We plan to gather information on the training, knowledge, and opinion of Japanese obstetricians in hospitals or clinics regarding multiple births, containing numbers of placenta and zygosity.

\section{Acknowledgments}

I gratefully acknowledge the help of Norio Yamanaka, the president of Bindeballe Publishing Company, and Dr. Yukiko Amau, the president of The Japanese Association of Twins' Mothers, who helped to collect twin samples.

\section{References}

Derom, R., Bryan, E., Derom, C., Keith, L., \& Vlietinck, R. (2001). Twins, chorionicity and zygosity. Twin Research, 4, 134-136.

Imaizumi, Y., \& Nonaka, K. (1997). The twinning rates by zygosity in Japan, 1975-1994. Acta Geneticae Medicae et Gemellologiae, 46, 9-22.

Machin, G.A. (1994). Twins and their zygosity. Lancet, 343, 1577.

Ooki, S., \& Asaka, A. (2004). Zygosity diagnosis in young twins by questionnaire for twins' mothers and twins' self-reports. Twin Research, 7(1), 5-12. 
Ooki, S., Yamada, K., \& Asaka, A. (1993). Zygosity diagnosis of twins by questionnaire for twins' mothers. Acta Geneticae Medicae et Gemellologiae, 42, 17-22.
Rietveld, M. J. H., van der Valk, J. C., Bongers, I. L., Stroet, T. M., Slagboom, P. E., \& Boomsma, D. I. (2000). Zygosity diagnosis in young twins by parental report. Twin Research, 3, 134-141. 